\title{
On the Tibetan Ge-sar epic in the late 18th century : Sum-pa mkhan-po's letters to the 6th Pan-chen
}

\section{Lama}

L'épopée tibétaine de Gesar à la fin du XVIII siècle: les lettres de Sum-pa

mkhan-po au $6^{e}$ Pan-chen Lama

\section{Solomon George FitzHerbert}

\section{OpenEdition}

\section{Journals}

\section{Electronic version}

URL: https://journals.openedition.org/emscat/2602

DOI: 10.4000/emscat.2602

ISSN: 2101-0013

Publisher

Centre d'Etudes Mongoles \& Sibériennes / École Pratique des Hautes Études

\section{Electronic reference}

Solomon George FitzHerbert, "On the Tibetan Ge-sar epic in the late 18th century : Sum-pa mkhan-po's letters to the 6th Pan-chen Lama", Études mongoles et sibériennes, centrasiatiques et tibétaines [Online], 46 | 2015, Online since 10 September 2015, connection on 13 July 2021. URL: http://

journals.openedition.org/emscat/2602 ; DOl: https://doi.org/10.4000/emscat.2602

This text was automatically generated on 13 July 2021 .

(c) Tous droits réservés 


\title{
On the Tibetan Ge-sar epic in the late 18 th century : Sum-pa mkhan- po's letters to the 6th Pan-chen
}

\section{Lama}

\author{
L'épopée tibétaine de Gesar à la fin du XVIII' siècle : les lettres de Sum-pa \\ mkhan-po au $6^{e}$ Pan-chen Lama
}

Solomon George FitzHerbert

\section{Introduction}

1 Any contemporary visitor to the eastern Tibetan regions of Khams and A-mdo (which include the eastern parts of the Tibetan Autonomous Region as well as the historically and culturally Tibetan regions of Qinghai, Gansu, Sichuan and Yunnan Provinces) will be struck by the contemporary visibility of 'Ge-sar Culture'. They will see shops, restaurants, hotels and bars carrying the name of this epic hero ; they will hear music and video-CD shops blaring out modern renditions of Ge-saric songs and theatrical performances; they will see statues of Ge-sar mounted on his horse at the centre of modern town squares; in the summer months they may also encounter local statefunded 'Ge-sar festivals', with Ge-sar-themed pageantry, horse-races and dances. And should such a visitor enter any of the Tibetan-language bookshops in these regions, they will see whole shelves given over to new books (in Tibetan) of Ge-sar tales (ge-sar rgyal-po'i sgrung), and volumes of scholarly anthologies and monographs in Tibetan on various aspects of the epic cycle. Looking a bit closer, they would find that many of these new volumes of Ge-sar epic tales on display are the edited transcriptions of the oral recitations by recent or contemporary Ge-sar bards (such as Grags-pa, bSam-grub, Tse-ring dbang-'dus and others) whose repertoires have been recorded at the statefunded Ge-sar research institutes dotted around the ethnically Tibetan, Mongolian and Monguor (Ch. tu-zu) regions of China. And they would find that these books are mostly 
published by state-funded provincial-level Nationalities Publishing Houses (mi-rigs dpeskrun-khang).

This prominence of 'Ge-sar Culture' in the eastern Tibetan regions requires some critical examination. At one level, it simply indicates the important place the Ge-sar epic occupies in Eastern Tibet popular culture - the Ge-sar epic as a well-loved folkloric locus for the expression of Tibetan popular pieties, heroic legends, highland aesthetics, aspirations and identity. However popularity alone cannot account for this public prominence, ${ }^{1}$ any explanation of which must also take into account the lavish state patronage that the Ge-sar epic has enjoyed and continues to enjoy in the PRC. It is on the back of this official state support, that 'Ge-sar Culture' has in recent decades become something like an officially-sanctioned umbrella beneath which Tibetans are finding ways to pursue cultural and religious renaissance and identity assertion, in ways which may only have incidental or tangential relevance to the sprawling epic tradition itself (Buffetrille 2009). Understanding this state patronage requires some historical context.

In the first place, this historical context consists in the Leninist roots of the Chinese Communist Party's policies on Nationalities. The Chinese Communist Party's adoption of the Ge-sar epic as an object of patronage began as early as the late 1950s. At this time the new Socialist China was still conducting its Soviet-led and inspired ethnographic mapping of its territories, and was still evolving its minority-region developmental strategies under the wing of thousands of Soviet 'advisers'. It was in this context that the Ge-sar epic found favour within the CCP's adopted Leninist discourse on both "nationality" and "class", in a way that was entirely analogous to the parallel phenomena in the Soviet Union. ${ }^{2}$ It had "national" value in that it gave expression to minority (Ch. shao-su min-zu) culture while also, by merit of being shared by Tibetans, Mongols and Monguors, it validated the useful idea of cultural affinity within the "big family" of nationalities that fell under the Chinese socialist state. It had further legitimizing value in terms of "class", on the grounds that it was an expression of folk as opposed to elite culture - the Ge-sar epic was (and still is) framed in official state discourse as reflecting the true aspirations of the downtrodden Tibetan masses, an epic tradition which was suppressed by the exploitative aristocratic and religious elites of the old society. Today, as socialist ideological discourse recedes in contemporary China, the patronage of Ge-sar is still validated in these terms, and Ge-sar patronage is commonly referenced in official government refutations of allegations of Chinese colonialism and cultural repression in Tibet.

4 Seen in this Soviet-inspired context, it is apparent that Chinese state patronage of Gesar is almost directly analogous to the similar (and equally fitful) state patronage meted out to popular minority-culture art-forms, including epics, among the nationalities of the Soviet Union (see for example Prior 2000 on the fitful Soviet patronage of the Kyrgyz Manas epic).

5 However, there is also a longer-term historical context to the current Chinese State patronage of Ge-sar, and this dates back to the Qing Dynasty. Manchu patronage of Gesar in the 18th century was part of a sophisticated Qing Imperial strategy of statecraft for the incorporation of its loosely-incorporated Inner Asian empire. ${ }^{3}$ For the Manchus, whose own roots lay in a northern Inner Asian martial cultural complex characterised by the prominence of shamanism and horseback hunting, ${ }^{4}$ the Ge-sar epic was seen as an instrumentally-significant form of cultural 'glue' for the knitting together the 
various Inner Asian peoples and tribes, and potentially furnishing a kind of corporate solidarity between the inner Asian peoples and the wider Manchu-governed Chinese Imperium.

\section{Ge-sar in the 18th century}

6 We see this attempt to enlist Ge-sar to Qing Imperial legitimacy, for example, in the sponsorship by Emperor Kang-xi of the collation, carving and printing of an edition of the Ge-sar epic in 1717. This Mongolian-language version entitled Arban jü̈g-ün êjen Geser qagan-u toguji "Saintly Biography of Geser Khagan, Lord of the Ten Directions", was, according to Damdinsuren (1957, p. 56) likely collected from the region north of the Blue Lake. ${ }^{5}$ It is interesting that although this is a Mongolian-language version, it presents Ge-sar explicitly depicted as a 'King of Tibet'. This, as well as the fact that many of the personal names found in this version appear to be phonetic renderings of their Tibetan equivalents (Ligeti 1951), is taken as evidence by scholars that the Ge-sar epic's origins are Tibetan rather than Mongol. The attempt to present the Ge-sar epic as kind of cultural glue for the Manchu Imperium is also particularly evident in the Chinese sub-title appended to the text - San Guo Shi, The Three Kingdoms. Here we see an effort to extend the legendary resonance of Ge-sar beyond the Tibeto-Mongol cultural domain by the (historically spurious) association between the Ge-sar epic and perhaps the main locus classicus of mythic warrior-heroism in Chinese popular lore - the Chinese historical epic of The Three Kingdoms set in the 3rd Century CE, which was given its final literary expression by Luo Guanzhong in the 14th century.

7 This Chinese sub-title also reflects one of the most interesting aspects of the Qing Dynasty's Inner Asian cultural diplomacy - namely its deliberate attempt to merge or assimilate the deified Tibetan-Mongolian epic figure of Ge-sar / Ge-ser - who has been propitiated in rites of 'smoke offering' (Tib. bsang-mchod) by Tibetans and Mongols alike as a protective deity of horses and livestock and the enemy-conquering raid at least since the late 16th century - with the Chinese martial deity and Imperial protector Guan-di, who was the apotheosis (the deified form) of Guan-yu (162-220 CE), one of Liu Bei's generals in The Three Kingdoms (on the apotheosis of Guan-yu see Duara 1988). ${ }^{6}$

By 1748, when Sum-pa mkhan-po Ye-shes dpal-'byor wrote his historical work the dPagbsam ljon-bzang, this assimilation between Ge-sar and Guan-di appears to have become quite established, and is bolstered by a further assimilation with the (especially) Mongol protector deity Beg-tse. In the dPag-bsam ljon-bzang, Sum-pa glosses the name Kwan-lo-ye (Guan-di) thus : "he is also said to be an incarnation of lJong-btsan Shan-pa, of Ge-sar, and of Beg-rtse" (Stein 1959, p. 112). Clearly the Qing dynasty sought to bolster its political legitimacy in Inner Asia through the assimilation of Ge-sar - as both a popular Tibetan and Mongolian heroic figure and protector deity - with the imperial guardian-deity Guan-di.

However the Qing Imperial elite was not alone in its efforts to harness the legitimating power of Ge-sar to its rule. Also during the 18th century, concerted efforts were made by the then-ascendant eastern Tibetan kingdom of sDe-dge to assert historical 'ownership' of the Ge-sar tradition. During the 17th century sDe-dge had absorbed the historic kingdom of Gling-tshang, a once powerful neighbouring Tibetan kingdom in Khams which had been instrumental, during the height of its power in the 14th-16th centuries, in the development and propagation of the Ge-sar legend and its 
development into an epic cycle. The royal family of Gling-tshang claimed direct descent from Ge-sar's fabled nephew and the hero's heir in the epic itself, namely dGra-lha Tshe-rgyal.

10 The legitimating power of textual production was an aspect of diplomatic statecraft which was well-understood in the ascendant Kingdom of sDe-dge in the early-mid 18th century. In 1729, sDe-dge's famous printing house (par-khang) was established, and the first editions of the so-called sDe-dge bKa'-gyur (Tibetan Buddhist canon) were printed four years later. It was only the following year, in 1734-1735, that attention was turned to the Ge-sar epic, when the minister (zhabs-drung) of the sDe-dge kingdom, Ngagdbang bstan-'dzin phun-tshogs composed what was to become a Tibetan literary classic, and arguably the most canonical text in the whole literary corpus of the Tibetan Ge-sar epic, namely the two-volume "Conflict Between Hor and Ling' (Hor-gling g.yul-'gyed). In the final chapters of this monumental work (over 1000 pages of modern print) it is Ge-sar's nephew Dgra-lha Tshe-rgyal (the fabled ancestor of the Gling-tshang kings, to whom the royal house of sDe-dge were in a sense, successors) who commands the swelling ranks of Gling as they make their final victorious assault on the crumbling enemies of Hor.

11 The oral tradition concerning Ge-sar was clearly very vibrant and alive in Khams at this time, and Ngag-dbang bstan-'dzin phun-tshogs has some claim to being considered as something akin to a Tibetan Elias Lönrot. According the colophon of the Hor-gling g.yul-'gyed, the text was compiled and composed on the basis of the oral tellings of no less than "some twenty bards". Some of whom are named: Lha-dbang tshe-ring from Nang-chen, Tshe-ring don-grub from sDe-dge, another Chab-mdo, and another from Gling and so on. The Hor-gling g.yul-'gyed, aside from its many literary merits, is also very interesting because it bears witness to the Ge-sar oral tradition in a period before the epic had been comprehensively swamped by the interpretative sensibilities of rNying-ma Buddhism - in other words before Ge-sar's role as a messenger (pho nya) of Padmasambhava came to dominate all other qualities of his heroic station. ${ }^{7}$ Instead we see an epic that is equally weighted between its chivalric dimension - as a tale of survival and honour concerning the horse-rustling tribe of Gling - and its 'shamanistic' dimension as a magical tale about a shape-shifting trickster hero. In this text Ge-sar's association with Padmasambhava is hinted at here and there, but it is by no means centre-stage.

During the same period as the Kingdom of sDe-dge was asserting some sense of "ownership" of the Ge-sar tradition by dint of its close connections to the Kingdom of Gling-tshang, there was also interest in Ge-sar by senior figures in Central Tibet. We see evidence of this in the production of a series of Ge-sar texts by a very senior religious and political figure of the time, namely the 5th Sle-lung sprul-sku, bZhad pa'i rdo-rje (1697-1740). Sle-lung was considered the reincarnation of Tsong-kha-pa's rdzogs-chen teacher, and as such his incarnation-line occupied a very elevated status in the Central Tibetan dGe-lugs-pa establishment. The Fifth Sle-lung's influence with the then (rNying-ma-pa-leaning) ruler of Tibet Pho-lha-nas bSod-nams stob-rgyal, was considerable. Indeed in 1731 Pho-lha-nas' main minister and right-hand-man Tshe-ring dbang-gyi-rgyal-po (1697-1763) commissioned a lengthy commentary from sle-lung on the completion stage practices of the Tantric deity gSang-ba ye-shes. ${ }^{8}$ It was only two years prior to this commission, in 1729 , that Sle-lung had recorded his "pure vision" (dag snang) of Ge-sar's theogony as a protective deity, ${ }^{9}$ and composed two texts of ritual 
offering to a form of Ge-sar known as Ge-sar rDo-rje tshe-rgyal to accompany it. ${ }^{10} \mathrm{As}$ further evidence of the favour given to Ge-sar by members of the Lhasa political elite, it is also notable that perhaps the most influential Central Tibetan lay political figure of the 1780s and 1790s, rDo-ring Pandita (rDo-ring Bstan-'dzin dpal-'byor) had a shrine to Ge-sar on the third floor of his home. ${ }^{11}$

This interest in Ge-sar by Tibetan political elites (both eastern and central Tibetan) in the mid-18th century was very likely influenced by the parallel Manchu imperial interest in this figure. Over the course of the 18th century, as Qing assertions of power over Tibet steadily increased, ${ }^{12}$ the Chinese Imperial martial protector Guan-di became an ever-more prominent figure in imperial circles. We see this in the fact that there was a shrine to Guan-di at Tashilhunpo monastery, which was apparently sacked by the invading Gurkhas in 1791 (Richardson 1974, p. 47). And as the 18th century progressed, the assimilation between Guan-di and the Tibeto-Mongol figure of Ge-sar/Ge-ser became ever more marked. This process reached its apogee in the wake of the Manchu military intervention to repel the invading Gurkhas in the early 1790s. Following this campaign, in 1793, a combined Ge-sar/Guandi chapel was established in Lhasa by the Manchu Amban Ho-lin and General Fu k'ang-an, upon the latter's return from the Gurkha campaign. This temple stands on the sPar-ma-ri hill below the Potala (Ferrari 1958, p. 92), and its founding is commemorated by an inscription (Richardson 1974, p. 53). From this time on, for the rest of the so-called Manchu Protectorate in Tibet (1720-1912), this Guandi/Ge-sar temple, curated by the dGe-lugs-pa monks of the nearby Kun-bde-gling monastery, served as the garrison temple for the small Chinese military force stationed in Lhasa. And it accordingly came to be known colloquially in Lhasa as the "Chinese Temple" (Tib. rgya mi' lha khang). ${ }^{13}$ The temple can still (in its recently renovated form) be visited today.

Clearly, then, the oft-stated idea that the Ge-sar epic was frowned upon by the elites of traditional Tibet ${ }^{14}$ requires substantial circumscription, since we can see here, clearly, that Ge-sar, as a kind of 'Tibetan form of Guan-di' was in fact embraced not only by the Manchu elite, but also by powerful sections of the Tibetan elite, and particularly those associated with the Qing Imperial court in the late 18th century. And the patronage of Ge-sar by Tibetan political elites outlived the Qing Imperium itself. In the period of Tibet's political independence from China after 1913, we find that the Rwa-sgreng Regent - who was the effective ruler of Tibet during the minority of the 14th (the present) Dalai Lama until 1941 - employed a personal Ge-sar bard. His name was Byams-pa gsang-bdag and he was later to become the chief informant for a number of seminal western Tibetological works. ${ }^{15}$

However it is fair to say that the Tibetan Ge-sar tradition has never been as strong in the central Tibetan provinces of dBus and gTsang as it is in both Khams and A-mdo. In these eastern provinces Ge-sar traditions - including masked dances and ritual propitiations - are carried on by a diverse range of monastic communities in the rNying-ma, Sa-skya and bKa'-brgyud schools, and many of our most seminal surviving Ge-sar texts from these regions were in fact authored by members of monastic and aristocratic elites. Indeed, even in modern times, it seems that the reception of Ge-sar was not so much a matter of religious approbation as it was of regional resonance. In eastern Tibet, as in Mongolia, Ge-sar was by no means anathema, even to dGe-lugs institutions. George Roerich, for example, in his excellent 1942 field-work based article on Ge-sar, states that "in A-mdo among followers of the dGe-lugs-pa sect one often 
hears the unexpected statement that Tsong-kha-pa himself, the Tibetan Reformer, had been once the chaplain (a-mchod) of King Kesar of Ling" (Roerich 1942, p. 286). The sense that Ge-sar epic was a 'waste of time' therefore seems to be sentiment that was primarily one that arose from the epic having only very shallow roots in the popular traditions of central Tibet, rather than any deeper hostility.

\section{The context of the exchange about Ge-sar between the 6th Pan-chen bla-ma and Sum-pa mKhan-po} written correspondence (dris-lan lit. "questions-answers") on the subject of Ge-sar between two of the most senior dGe-lugs-pa establishment figures of the period, namely the de facto ruler of central Tibet in the 1770s, the 6th Pan-chen bla-ma Blobzang dpal-ldan ye-shes (1738-1780), and the renowned (dGe-lugs-pa) scholar, historian, diplomat and lama Sum-pa mkhan-po Ye-shes dpal-'byor (1704-1788). The questions came from the Pan-chen, and the answers from Sum-pa. The remainder of this article will explore the context of this exchange, and present it in full English translation. Sum-pa mkhan-po's comments on Ge-sar in this exchange, the source of which he says, were conversations with elders in sDe-dge, remain one of our most important primary sources on the history and development of the Tibetan Ge-sar epic tradition, and are regularly cited by contemporary Tibetan scholars. It is on the basis of this exchange, above all, that Sum-pa mkhan-po is sometimes hailed as a beacon of rationality and critical investigation in the Tibetan scholarly tradition.

According to his autobiography, Sum-pa mkhan-po Ye-shes dpal-'byor was born to Mongol parents (his father Oirat, his mother Jungar) in the A-mdo grasslands between rMa-chen sPom-ra and the rMa-chu river in 1704, and he considered himself to belong to the Baatud tribe of the Oirat Mongols. Recognised as the reincarnation of a senior Tibetan lama, however, his Tibetan education and the cultural milieu of his life was very much embedded in Tibetan Buddhism of the time, and he identified as much with his Tibetan incarnation lineage as with his natal identity as a Mongol (Erdenibayur 2007, pp. 304-306). His monastic seat was at the major dGe-lugs-pa centre of dGon-lung, located east of Xining in the heart of the Monguor (Ch. tu-zu) lands - at the juncture of the Tibetan, Mongolian and Chinese cultural worlds. This was also the monastic seat of the hugely influential "Grey-Willow" lCang-skya incarnation lineage, the scions of which were so instrumental in Tibetan-Qing relations during the 18 th century. ${ }^{16}$

Sixth ${ }^{17}$ Pan-chen bla-ma Blo-bzang dpal-ldan ye-shes on the other hand was the most prestigious religious and political figure in the Tibetan world in the 1770s. He was born to aristocratic Tibetan parentage. His older half-brother was the 9th Zhwa-dmar$\mathrm{pa}$, incarnation, the second-most senior lineage-holder in the Karma bKa'-brgyud school. It was this brother who was deposed after the Pan-chen's death for his complicity in the Gurkha invasion of Shigatse in 1791.

During the minority of the 8th Dalai Lama, it was the aristocratically-born, energetic and politically-active Pan-chen who was the de facto ruler of Tibet. This is attested to in the Pan-chen's 1774 letter to the then head of the British East India Company in Bengal, Warren Hastings. This letter, which was delivered to Bengal by a Tibetan envoy named Padma and a Hindu Gosain named Purangir, ${ }^{18}$ was an attempt on the part of the Pan-

Études mongoles et sibériennes, centrasiatiques et tibétaines, 46 | 2015 
chen Lama to resolve a conflict that had erupted between the British and the then ruler of Bhutan over the region of Cooch Bihar. ${ }^{19}$

This de facto status as ruler of central Tibet, led shortly afterwards to the East India Company despatching their first ever envoy to Tibet to Shigatse, where the young Scot George Bogle stayed as the guest of the Pan-chen Lama for several months in 1774-5. Bogle's testimonies paint an interesting picture. The erudite Pan-chen (who rarely among his Tibetan contemporaries, knew Sanskrit), conversed with Bogle in Hindustani. ${ }^{20}$ We also hear that he was engaged in active diplomatic and trade relations with both the ascendant Gurkha monarchy, and the then Raja of Benares, Chait Singh (r. 1770-1781). ${ }^{21}$ Bogle was also astonished at the vast apparent reach of the religion of Tibetan "Tartary", over which the Pan-chen's religious status reached. In this period, the reach of Tibetan religion extended, as Sum-pa points out in his autobiography, from the mythical holy sites of India in the west ${ }^{22}$ to the great ocean in the east, encompassing all the lands between : Nepal in the west; the "three circuits" of Ngari (western Tibet); the "four horns" of dBus and gTsang (central Tibet); mDo-khams (eastern Tibet) ; the "thirteen provinces" of China in the east; and all the lands of the four tribes of Oirats, the seven tribes of Khalkha, and forty-six Mongol tribes. ${ }^{23}$

The exchange between these two exalted figures on the subject of Ge-sar took place on the eve of the Pan-chen's historic visit the Manchu court for the occasion of the Qianlong Emperors 70th birthday. ${ }^{24}$ Qianlong's reception of the Pan-chen was to take place at the fairytale imperial summer residence at Chengde (c. $250 \mathrm{~km}$ northeast of Beijing), where a replica of Tashilhunpo was being built to house the visiting Lama, near the replica of the Potala already in place. ${ }^{25}$ It was in anticipation of this visit that the Pan-chen sought clarification from Sum-pa concerning the identity and history of Ge-sar - once again attesting to the significance of Ge-sar in this period as a significant locus of Qing-Tibetan cultural diplomacy.

The Pan-chen departed in September 1779 and after crossing first the Tang-la pass and then the 'Bri-chu River (Upper Yangtze), he was met by envoys of (the almost octogenarian) Sum-pa mkhan-po before he reached rMa-chen spom-ra, the great mountain range in mGo-log. The two lamas then actually met in person in midNovember before the Pan-chen reached sKu-'bum, where he would stay for several months over the Tibetan New Year of early 1780. It was during this first meeting (i.e. before arriving at sKu-'bum), which is described very poetically in Sum-pa's autobiography, that the Pan-chen requested Sum-pa to give him further explications on a number of issues which the Pan-chen had previously taken up with Sum-pa in a letter - in particular on how to calculate the arrival of the comet du-ba mjug-ring; and (what concerns us here) on the figure of King Ge-sar, the hero of the Tibetan epic tradition. He asked Sum-pa to give a detailed account of these issues, to put them in writing, and to bring this with him when they were to meet again at sKu-'bum. ${ }^{26}$ When the Pan-chen says, in this historical context that an account of Ge-sar would be "useful" (phan par), one can only assume that the 'usefulness' had to do with his upcoming audience with the Qianlong Emperor. Immediately prior to their meeting in the winter of 1779-1780, Sum-pa had spent eight years in Mongolia, and presumably this was part of the reason for the Pan-chen asking Sum-pa about this subject. Sum-pa would be someone particularly well-qualified to assess the historical origins of the Ge-sar legend, due to his knowledge of both Tibetan and Mongolian culture..$^{27}$ 

burgeoning diplomatic and political instrumentality of the epic in this period ; we also see the Ge-sar epic's ambivalent socio-religious status for these senior Buddhist figures ; and we also gain a window state of the epic narrative tradition itself in the late 18th century. It is notable that no mention is made in this exchange of the assimilation of Ge-sar with Guan-di. This is somewhat surprising, though I see awareness of this as an unspoken understanding which underlies the exchange. R. A. Stein states that the Pan-chen composed a ritual for Guan-di at the same time - 1779-1780 (Stein 1959, pp. 112-113). However Stein was unable to locate this text, and I too have not found it. That he should have done so, however, makes perfect sense in the context, and should the text come to light, it could further illuminate the diffusion of this syncretism.

\section{The content of the exchange}

While the context of this exchange illustrated the diplomatic instrumentality of the Gesar epic in Tibetan-Mongol-Qing relations in the late 18th century, the content of the exchange is revealing on a number of issues. Sum-pa gives us an important testimony on the state of the Ge-sar epic in this period, based, he says, on "what I heard from elders in sDe-dge". This account of the epic narrative and his conjectures concerning the history of the epic are of great interest to any historian of the epic, and the correspondence reveals a number of interesting perspectives. Both lamas hint at the 'international' resonances of the Ge-sar legend in this period, as discussed above. For example we see the Pan-chen probing a possible mytho-geographic connection between a Ge-saric battle, and the death of Chinggiz Khan in the A-mdo borderlands. And in Sum-pa's answers, the Ge-sar tradition is likened to Chinese popular storytelling traditions - namely the tales concerning Thang-seng Lama - the Tibetan name of the chief protagonist in the Chinese popular storytelling tradition known as the Journey to the West, or more commonly in the West as Monkey! Cognizant of the Panchen's diplomatic mission as a possible reason for his queries concerning Ge-sar, he also mentions that the stories of Ge-sar are performed in front of the Qing "Manjushri" Emperor himself.

On the religious status of Ge-sar, we see a certain scepticism on Sum-pa's part. He is clearly not deferential towards Ge-sar - when describing his birth he uses the nonhonorific skyes not 'khrungs for "born", and he states explicitly that although people claim Ge-sar to be this and that emanation, he does not regard Ge-sar as a particularly holy or venerable figure. But on the other hand he is far from dismissive of the epic as a cultural tradition - he compares it for example to the oral tradition which sustained the Hindu Vedas. He is also willing to entertain the suggestion that Ge-sar was the incarnation of local mountain divinity in Eastern Tibet - a worldly, rather than an enlightened spirit.

Sum-pa's replies also illustrate his concern to assert the Tibetanness of Ge-sar. This is interesting, especially given Sum-pa's own Mongol ancestry. Rather than pointing to the Mongolian cultural borrowings exhibited by the Tibetan Ge-sar tradition (which are many - even the Tibetan word for "warrior" used in the epic - dpa' rtul - is for example a borrowing from the Turko-Mongol batyr/batur) instead Sum-pa recounts a variety of local Tibetan Ge-saric traditions, two of which are particularly salient in his account. The first are the legends concerning Ge-sar's birth in the region of Gling-

Études mongoles et sibériennes, centrasiatiques et tibétaines, 46 | 2015 
tshang and 'Dan-ma, near sDe-dge, in Khams. He gives detailed information concerning Ge-sar's reputed birth, referring to landmarks still pointed out today near the village of A-phyug (within the former domains of the kingdom of Gling-tshang). And from these legends he is happy to assert that Ge-sar should be considered a real historical figure, and that he can't have lived very long ago. And the second, are some legends concerning Ge-sar from central Tibet. These are of particular interest because Central Tibetan legends concerning Ge-sar are rather less common than those to be found in the eastern regions of the Tibetan world. Here he gives the account of Ge-sar's great adversary, the Demon (bdud) King, being associated with the Nag-tshang region north of Lhasa, and Kong-po in southern Tibet as the abode of demons (indeed there is often a conflation in Ge-sar tales between Ge-sar's adversary the demon bDud klu-btsan, and the mythical demon of Kong-po, A-chung rgyal-po).

It is also interesting to take note of Sum-pa's comments concerning the relationship between the Ge-sar legend and local traditions concerning local mountain deities ( $r i-$ gnyan gzhi-bdag). The idea of local mountains (ri) being abodes of authoritative ancestral deities (gnyan), which are "territorial lords" (gzhi-bdag) or local deities, is part of what is often described as a prominent part of Tibet's "secular" or lay culture (see for example Karmay 1996). This aspect of Tibetan culture is generally regarded as having been discouraged by the Buddhist formalism of dGe-lugs tradition. However this again is clearly a simplification - here we have such a tradition being openly validated by Sum-pa. Indeed it is also of interest to note that in the Pan-chen Lama's collected works (gSung-'bum, volume ja), there are a variety of propitiatory works (mchod pa) for local deities (gzhi bdag or yul lha), indicating that such practices were very much alive within dGe-lugs tradition at that time.

Of particular interest is the name of the mountain deity that Sum-pa reports Ge-sar may have been an incarnation of. He names it as Gom-pa ra-tsa. Well this name is very interesting, because by the time the so-called Gling-tshang woodblock edition of the Ge-sar epic was composed in the early 20th century (now available in full English translation in Kornman et al. 2012), Gom-pa ra-tsa features not as a local territorial divinity and Ge-sar's backer, but rather as a heretical sorcerer whose attempt to kill the infant Ge-sar soon after his birth, constitutes a major sub-plot (see Kornman et al. (trans) 2012, pp. 222-240 ; Stein 1956 vol. 2, fol. 35b-43b). We have here a very clear example of how the epic narratives concerning Ge-sar can change over time, and the folkloric process that Vladimir Propp described as "the demotion of former idols". A figure of Gom-pa-ra-tsa remains associated with the mountain above the reputed site of the hero's birth, but the role of that figure changes from that of local presiding deity, to villainous heretic, as the epic tradition becomes ever more Buddhiscised in the hands of a hegemonic Buddhist literary culture.

Similarly interesting is Sum-pa's account of how Ge-sar kills his demon-adversary. Sum-pa's account of this duel places a strong and dualistic emphasis on the nonBuddhist Tibetan concept of bla - or "soul" - again a salient feature of Tibetan indigenous rather than Indic Buddhist belief. Nowhere to be seen, in his account are the Vajrayana, Rudra-slaying models of demon-subjugation, which over time have come to dominate the interpretative "mental texts" (Honko 2000) of Tibetan Ge-sar story-tellers and authors. 

a very good and concise introduction to the cultural milieu and the narrative frame of the Ge-sar epic as witnessed by Sum-pa mkhan-po in the late 18th century.

\section{The Content of the Exchange}

From the Pan-chen bla-ma Blo-bzang dpal-ldan ye-shes, to zhabs-drung Sum-pa mkhanpo ye-shes dpal-'byor (translated from Damdinsuren 1957, pp. 184-185) :

In (your) religious history (chos 'byung) ${ }^{28}$ when you mention Hor, it is suggested that the part of it nearest to Tibet is called Yugur. Now I have heard it said that while fighting with Ge-sar, one of the main chiefs of Hor, called Sky-King Gur-ser of Yellow Hor, had his residence, which was a great castle, completely destroyed. Now since you yourself have mentioned that the place where Chinghiz Khan (cing-gi-se rgyal-po) died was a river-crossing near the castle of Shirigol (zhi-ril-gwol), it seems that the castle, in terms of region, condition and whatever other aspects, may be one and the same place?

So tell me : when did this King Ge-sar appear? During the reign of which king of Tibet? According to the history of Byang-chub 'dre-bkol [i.e. the Rlangs po-ti bse$r u]^{29}$ the great master (slob-dpon i.e. Padmasambhava) said to dPal-kyi seng-ge, in the presence of King Khri-srong lde-btsan and so on, that "in the 12th generation you shall gain dominion over gods, demons and men" and thus it was prophesied that Byang-chub 'dre-bkol would become the Lama of Ge-sar. Now if you can give me an account, unadulterated by worldly oral tales, of this king - when, how and what he did - I would consider this useful (phan par). Kindly send your detailed answer.

Sumpa's response was as follows (translated from Sum-pa's gSung 'bum vol. nya fol. 189, line $7 \mathrm{ff})$ :

Although it is said by many Mongols that Chinggiz Khan of Hor was killed by the queen of Mi-nyag [i.e. Xi-xia], according to the "great Yellow Annals" of China (rgyanag gi yig-tshang che-ba), this queen wasn't able to kill him, and he in fact died at sNgad-chu-nag in rMa-chu [upper Yellow River, A-mdo]. [fol. 190] Later the king was also said to have died at a place called Cha-ghan-pal-gwa-su which is between Zhi-ra-gwol and Yu-gur [north of the Blue Lake].

Now as for the history of Ge-sar, well it is comparable to the tales of the Chinese monk Thang-seng bla-ma [the monk in The Journey to the West/Monkey], in that although his real life story is quite another thing, various stories are told about him these days, and are even performed as dances (zlos-gar) before the great [Qing] Manjuśri Emperor ('jamdbyangs gong-ma chen-mo). In a manner similar to the oral tradition of the Hindu Vedas, the stories are embellished and poeticised and told in all kinds of ways.

Well as for Ge-sar himself, he is said to have been born at a place called sKyid Nyi-ma kun-'khyil, a Gling-ba place to the left [i.e. north, when facing east to face the emperor] of the territories of sDe-dge in Upper Khams (stod-khams). Ge-sar later defeated Hor Gur-ser, king of the Yu-gur Ho-thon tribe, whose castle, Ya-rtse mKhar-dmar, is to the "upper left" [north-west?] of sDe-dge. Nowadays the territories of that tribe - the "eight tribes of Zhi-ra-gwol" - lie beyond the Blue Lake. If Ge-sar stories are recounted in that place, the local spirits do harm to horsemen. Formerly this was also the place where Pe-dkar resided, in the retreat of Bandha Hor which was destroyed and whose remains are still visible. 
Although it is unknown exactly when Ge-sar lived, I suspect it may not be too long ago, since I have heard that his arrows, bows and so on, and his descendants and so on from his real blood-line, still exist today in Khams.

Then, when the Pan-chen and Sum-pa met again in A-mdo in the winter of 1779-1780, as described above, the Pan-chen asked again for further clarification and detail on this issue. The written response that Sum-pa brought with him to give to the Pan-chen at sKu-'bum monastery that winter, runs as follows (fol. 196, line $6 \mathrm{ff}$.) : ${ }^{30}$

In China, Tibet and Mongolia (hor), the stories of Ge-sar are told in poetic fictionalised ways, but he seems to have been a ordinary person, as it is hard to rely on the many competing accounts saying that he is this or that emanation, so it is rather hard to make a considered judgement about whether he was an ordinary person or an incarnation [fol. 197].

So if we just consider the repute of Ge-sar as an ordinary being, well with regard to his place of birth : if you go up from upper Bar-khams to the area between the rMa-chu, rDza-chu and 'Bru-chu [sic. 'Bri chu] rivers, to the place where the rDza-chu meets the two rivers of sKye'u-gzhung and Tsha-lung-ba, there is a confluence of three rivers. That place is to the "left" of the sDe-dge palace and is included in the territory of sDedge. Well the actual birth place, in the upper part of that valley there is a small lake like a mirror, and a confluence of two rivers, and there are four ridges on a small rocky hill and between them is a flat meadow laid out like a carpet. There a tree grows, and there is a flat stone, a remnant of his parents' tent having being erected there. And it is said that this place is called sKyid Nyi-ma kun-'khyil. ${ }^{31}$ Above that place, three rivers - the Khang-chen lung-ba, the Yag-nye'i-chung and the rDza-chu - unite in front of Tiger Mountain (stag-ri), where there is a small hill shaped like a heart.

8 Below that, in the upper reaches of a rocky mountain, resides a powerful ancestral territorial divinity (gzhi-bdag gnyan-po) ${ }^{32}$ called Gom-pa-ra-tsa, ${ }^{33}$ and in front of that rocky mountain there are thirty cairns which are said to be Ge-sar's thirty kinsmen.

As for the (patrilineal) clan (rus) of Ge-sar, in the land of Bar-khams sDe-dge, there are two major communities (sde), the Gling-ba and the 'Dan, and he was a Gling-ba. Nowadays the Gling-ba are not under sDe-dge, while the 'Dan are.

Now as for Ge-sar, his father was Sing-rlom and his mother 'Gag-rus. ${ }^{34}$ Some say that since the people of Gling and 'Dan were frequently attacked by brigands they would regularly make smoke offerings (bsang) to the territorial divinity of an ancestral mountain (ri-gnyan zhig gi gzhi-bdag) in that place seeking protection, and it is said that Ge-sar was born as that territorial divinity itself or as its emanation. Such a thing is possible because for example even recently the wife of a nomad who regularly made offerings to her ancestral mountain (ri-gnyan) in the land of mDong-nag, gave birth to a child, Tsha-bo 'Jam-dbyangs rab-'byams who is recognised by all, both lay and monastic, as the son of that place's territorial divinity (gzhi-bdag).

Then soon after Ge-sar's birth, his own uncle Khro-thung exiled him to Lha-lung g.yumdo, near the (poison) lakes [called] sKya-rangs and sNgo-rangs at the source of the rMa-chu river. Having settled there (gzhi bzung nas) he grew up brave and skilful. In that place, not far from a small mountain known as 'Ge-sar's mdzo-tying place', there is said to be a plain called the "poison-plain of A-ba" (A-ba phyi-dug-thang) where the Hor army was encamped, and this is also stated in the biography of the Great Fifth [Dalai lama] (vol. $k a$, fol. 181). As for this Ge-sar, he was a mighty, athletic and fiercely intelligent man. He took two wives - Me-za 'Bum-skyid [fol. 198] and the daughter of 
Gling sKya-li, called 'Brug-mo-skyid, and these were respectively the elder and younger [wives]. His horse was called rKyang-rgod g.yer-ba.

Now, as for the Demon (bdud) that Ge-sar later defeated, well to the north of Lha-sa, in the direction of gNam-mtsho phyug-mo, in the areas of the Gre-ba Nag-tshang [tribe], a mighty fellow was born between the places called Gu-ru and Mon-ra. The people of that area, the Nag-tshang-ba, are themselves said to be a tribe of demons (bdud kyi ru-sde). Well, this fellow then migrated in the direction of Lha-sa to the Kong-po area. In that land there is a river-source where the water is poisonous or stupefying and whoever drinks it goes half-mad, and it is said that all the people and animals there [behave] as if they are drunk ( $r a-r o$ 'dra). Well, that fellow drank that water. In that land in the middle of a "demon soul mountain" (bdud kyi bla-ri) called Ha-shang rTse-dgu there are three small lakes, and if the water of these lakes is mixed, it is a said that a demon will be born. Well, this fellow drank the poison-water and then combined the water of the three lakes, and as a result he himself was considered to have turned into a demon in the land of men. Then he went to 'Dam [north-east of Lha-sa] where he dwelt in a fort made of deer horns and bones called the Demon-Fort (bdud-mkhar) Sha-ra gnamrdzong, and there engaged in banditry (jag byed).

One time, on a plundering expedition, he came to the land of Gling. At that time Ge-sar was away hunting or raiding another country, so he kidnapped and made off with Gesar's girl Me-za 'Bum-skyid and her sibling Phying-sngon-can. When Ge-sar returned home and heard about this, he set off like a raider and crossed the gShed-chu-khams-pa into the Demon's country. When he arrived, the Demon had gone on a raid and so [instead] he met Me-za 'Bum-skyid. She hid Ge-sar in the cellar, and told him how he could kill the Demon. When the Demon returned home he slept for the night. Then the next day at the very break of day, from the Demon's nostrils came two snakes, one black and one white, which then fought on his face. When the black snake - the "soul" (bla) of the Demon or some kind of spontaneous fiendish creature ('dre) - came to the centre of his forehead, Ge-sar fired an arrow at it and killed the snake-like thing and the Demon at the same time. It is said that Ge-sar then spent the next nine years with Me-za in the Demon's land [fol. 199].

Meanwhile the raiding armies of the Hor chiefs Gur-dkar, Gur-ser and Gur-nag went to the land of the Gling-bas. They killed Ge-sar's elder kinsman (mes po) rGyad-cu Zhaldkar (sic. rGya-tsha Zhal-dkar) [Ge-sar's older brother], and [attacked] the thirty kinsmen of Gling and so on, and carried off A-khu Khya-rgan (sic. A-khu Khra-rgan) [Ge-sar's Uncle] and 'Brug-mo and so on, and Gur-dkar took 'Brug-mo-skyid as his queen.

Now the lands of the Gling-bas and the Hor-pas were not far from each other. That is to say at the head of A-che-na valley which is above Chu-dmar, on the left side of the 'Seven Enclosures' of the 'Bru-chu (sic. 'Bri-chu), is a snow mountain called Gang-chags dKar-po, and below that is a large rock-mountain on the side of which was located the Red Ya-rtse dmar-mkhar castle of the Hor King Gur-dkar. And it is said that a wall still remains of this castle, and that where Ge-sar struck it with an iron chain, red fragments are still visible today. I have heard accounts from those who have seen and heard (gtam mthong thos kyi mi las) that in some ravines of that mountain, there dwell "sword ghosts" (gri-'dre) of the Hor-pa soldiers who were formerly killed there, and since they are non-human magical illusion-like beings (chos-'phrul lta-bu), even now at night, ordinary people don't dare go to that place. 

the Gling-bas had been defeated by the Hor soldiers, he led a large army of Gling-bas to the Red Ya-rtse dmar-mkhar castle of Hor. There he used an iron chain to swing [himself] inside the fort, and then opened the gates to his entire army. The Hor chief and many soldiers were killed, and at that time it is said that seven skilled warriors from the Hor army - the Ya-ba skya-bdun - escaped together with their followers. Then, taking [his uncle] A-khu Khya-rgan (sic.) and [his wife] 'Brug-mo with him, Gesar returned home. his horse got startled and threw him, and it was from this [fall], it is said, that he passed away. Since then the people of 'Dan-ma have had to pay an indemnity (stong mjal) for Ge-sar, which is like a tax that they have to give to the Ling-bas every year. Indeed at the so-called Thang-chung lhakhang (temple) in the land of 'Dan, ${ }^{35}$ there is a large pile of stones to which it is said even now that if the 'Dan-mas add a stone each year carved with the mani, that the land will be well [fol. 200]. And for that reason, in that land there is a saying : "there is no end to the paying of Ge-sar's blood-price ; there is no end to the wealth of 'Dan-ma" (ge-sar gyi stong-mjal-ba la tshar-rgyu med/'dan-ma'i rgyu-chas la 'dzad-rgyu med).

At that time the people of Gling and 'Dan and the Demon land, and the people of Hor, had no shared emperor or firm common law, so each of them did as they pleased. In those days, naturally enough, due to the people's pride in bravery, they were probably engaged in frequent conflicts arising from their raids on one another.

As mentioned before, near the remains of the Ya-rtse-mkhar-dmar at the foot of the rock mountain and A-chen Gang-chag dKar-po, are the remnants of King Gur-dkar's settlement, and the descendants of the Ya-ba sKya-bdun and so on. And in the inner part (phugs) of their tents they keep a narrow post (ka-ba phra-ma), at the tip of which they attach a small stick at a slant, which is a sign to represent how Ge-sar defeated Hor in the past, and how in victory he "placed a yak saddle on every tent". ${ }^{36}$ Also about seven or eight days to the north of the Blue Lake, beyond Pha-stong and the Shug-sha River but on this side of the Chinese Su-gru fort, are the descendants of Hor Gur-ser's clan, known as the Eight Tribes of the Sha-ra Yu-gur. Their language is like Ho-thon, but their appearance is unlike any others in China, Tibet or Mongolia. That [place] is also called Bandha Hor, and in that place there is a custom of keeping a black board (nag byang) across the "waist" of every tent, and this is said to be a sign that before, when Ge-sar defeated Hor, the tent was rent by [his] sword. In both the tradition of the A-chen and the Hor of Upper Blue Lake, since they fought with the Gling-bas in the past, the ghosts (gre-'dre sic.) of those that were killed were reborn as spirits (lha-'dre) in the lineage of the followers of the Kings Pe-dkar and Pe-ser and so on (pe-dkar-po ser rgyal-po sogs), and even now exist as such.

In these places if the tales of Ge-sar are recounted when they ride out (rta rkyang zhur zhon nas) then the spirits do them harm. Nowadays in various parts of Khams such as Chab-mdo, some of the Thirty Kinsmen [of Ge-sar] and so on of Gling are said to be reborn as something like territorial divinities, and it is said they possess people (khog la zhugs) and give prophecies. Likewise in various $\mathrm{Yu}$-gur areas, the Gur kings and various warriors have been reborn as spirits and there are oracles and mediums (lha-ba la bab$p a$ 'dug-go) [into whom they descend] [fol. 201].

Études mongoles et sibériennes, centrasiatiques et tibétaines, 46 | 2015 
51 I do not think that Ge-sar existed very early. In the Lho-g.yu-phugs temple in the Chabmdo area, there is a two-volume set of Ge-sar's original prajñāparamitā scriptures, with each volume constituting a yak-load. I have also heard from those who have seen them that there are also the swords of Ge-sar and A-me and the thirty kinsmen, which are a little bigger than the swords nowadays. Also, in a few other temples in dBus and gTsang, Ge-sar's hat and arrows and so on can be seen.

All this information comes from what I heard from elders in sDe-dge, and though I am not sure about some points, most of it is a faithful account.

\section{BIBLIOGRAPHY}

\section{The sources}

This written correspondence (though without the Panchen's first letter of enquiry) is found on folios 10-16 of Nang don tha snyad rig gnas kyi gzhung gi dogs gnas 'ga' zhig dris pa'i lan phyogs gcig tu bris pa rab dkar pa sangs, in volume nya of Sum-pa mKhan-po's gSung-'bum. According to the late Gene Smith of Tibetan Buddhist Resource Center Library (TBRC), ${ }^{37}$ there exists only one blockprint edition of this gSung 'bum which was printed in Dolonor in Inner Mongolia and then reprinted by Lokesh Chandra (TBRC ref. W29227). These prints are hard to read in places. Fortunately however, the Mongolian scholar Tseten Damdinsuren also faithfully reproduces the correspondence in Tibetan and cited his source as volume ja of Blo-bzang dpal ldan ye shes' gSung 'bum (Damdinsuren 1957, pp. 184-191). The correspondence is also reproduced in Tibetan in a recent collection of Tibetan historical sources relevant to Ge-sar studies : gNa' deng mkhas pa'i ge sar sgrung skor gyi gsung sgros gzi yi mgul rgyan. ${ }^{38}$

\section{Western Language Works Cited}

Buffetrille, $\mathrm{K}$.

2009 'May the New Emerge from the Ancient ! May the Ancient Serve the Present !' The Ge-sar Festival of Rma chen (A mdo 2002), in R. Vitali (ed.), The Earth Ox Papers, Proceedings of the International Seminar on Tibetan and Himalayan Studies, held at LTWA, September 2009. Tibet Journal, Autumn 2009, XXXIV, 3-Summer 2010 XXXV, 2, pp. 523-554.

Chayet

1985 Les Temples de Jehol et leurs Modèles Tibétains (Paris, Éditions Recherche sur les Civilisations).

Damdinsuren, Ts.

1957 Istoricheskie korni Geseriady (Moskva, Izd-vo Akademii nauk gobl.).

Das, SC.

1902 Journey to Lhasa and Central Tibet (London, Murray). 
Duara, $\mathrm{P}$.

1988 Superscribing Symbols : The Myth of Guandi, Chinese God of War, Journal of Asian Studies, 47, 4.

Erdenibayur

2007 Sumpa Khenpo Ishibaljur : A Great Figure in Mongolian and Tibetan Cultures, in Bulag \&

Diemberger (eds), The Mongolia-Tibet Interface (Leiden, Brill), pp. 303-314.

Ferrari, A.

1958 Mk'yen brtse's Guide to the Holy Places of Central Tibet, Serie Orientale Roma, XVI (Roma, Instituto Italiano per il Medeo ed Estremo Oriente).

FitzHerbert, S. G.

2010 A Modern Version of the Birth of Ge-sar, in S. Arslan \& P. Schwieger (eds.), Tibetan Studies : An Anthology. Proceedings of the 11th Seminar of the International Association for Tibetan Studies Königswinter 2006 (Halle, International Institute for Tibetan and Buddhist Studies), pp. 215-254.

Gellner, E.

1990 The Dramatis Personae of History, East European Politics and Societies, 4, pp. 116-133.

Honko, L.

2000 Text as Process and Practice : The Textualization of Oral Epics, in Honko L. (eds.)

Textualization of Oral Epics, Trends in Linguistics, Studies and Monographs 128 (Berlin, Mouton de Gruyter), pp. 3-54.

Hummel, S. (trans. Vogliotti)

1998 Eurasian Mythology in the Tibetan Epic of Ge-sar (Dharamsala : Library of Tibetan Works and Archives).

Karmay, S.

1996 The Cult of Mountain Deities and Its Political Significance, in Blondeau \& Steinkeller (eds.), Reflections of the Mountain (Vienna, Verlag der Österreichischen Akademie der Wissenschaften), pp. 59-75. Also in Karmay 1998 The Arrow and the Spindle, 1 (Kathmandu, Mandala), pp. 432-450.

Kornman, R., Sangye Khandro \& Lama Chonam (trans.)

2012 The Epic of Ge-sar of Ling: Ge-sar's Magical Birth, Early Years and Coronation as King (Boston, Shambhala).

Kun mchog dge legs, Dpal ldan bkra shis \& Kevin Stuart

1999 Tibetan Tricksters, Asian Folklore Studies, 58, 1, pp. 5-30.

Ligeti, L.

1951 Un Épisode d'Origine Chinoise du "Geser-Qan," Acta Orientalia Academiae Scientiarum

Hungaricae, I, pp. 339-357.

Loo, Margaret Shu-yi

1970 The Biography of the III Panchen Lama, Blo-bzang-dpal-ldan-ye-shes-dpal-bzang-po, Examined in Light of Sino-Tibetan Relations during the Late Eighteenth Century. PhD. Dissertation, University of Washington.

Martin, T.

2001 The Affirmative Action Empire : Nations and Nationalism in the Soviet Union 1923-1939 (Ithaca, Cornell University Press).

Millward, J. et al. (eds.)

2004 New Qing Imperial History: The Making of Inner Asian Empire at Qing Chengde (London, Routeledge Curzon). 
Nebesky-Wojkowitz, R. de

1956 Oracles and Demons of Tibet : the Cult and Iconography of the Tibetan Protective Deities

(Gravenhage, Mouton).

Petech, L.

1950a China and Tibet in the Early XVIIIth Century : History of the Establishment of the Chinese

Protectorate in Tibet (Leiden, Brill).

1950b The Missions of Bogle and Turner according to the Tibetan Texts, T'oung Pao, 2nd Ser., 39, pp. 330-346.

Prior, D.

2000 Patron, Party, Patrimony: Notes on the Cultural History of the Kirghiz Epic Tradition (Bloomington, Papers on Inner Asia No.33)

Rawski, E.

1998 The Last Emperors : A Social History of Qing Imperial Institutions (Berkeley, University of California Press).

Richardson, H. E.

1974 Ch'ing Inscriptions at Lhasa, Serie Orientale Roma, XLVII, 47 (Roma, Instituto Italiano per il Medeo ed Estremo Oriente).

Roerich, G. N.

1942 The Epic of King Kesar of Ling, Journal of the Asiatic Society of Bengal, VIII, 7, pp. 277-311.

Schram, L.

1957 The Monguors of the Kansu-Tibetan Border Part II : Their Religious Life, Transactions of the American Philosophical Society, New Ser., 47, 1, pp. 1-164.

Sperling, E.

1998 Awe and Submission : A Tibetan Aristocrat at the Court of Qianlong, The International History Review, 20, 2, pp. 325-335.

Stein, R. A.

1956 L'Épopée tibétaine de Ge-sar dans sa version lamaïque de Ling (Paris, PUF).

1959 Recherches sur l'épopée et le barde au Tibet (Paris, Presses Universitaires de France).

1962 Une source ancienne pour l'histoire de l'épopée tibétaine : Le Rlangs po-ti bre-ru, Journal Asiatique, 250, pp. 76-106.

Stewart, G. T.

2009 Journeys to Empire : Enlightenment, Imperialism and the British Encounter with Tibet, 1774-1904

(Cambridge, Cambridge University Press).

Teltscher, K.

2006 The High Road to China. George Bogle, the Panchen Lama and the First British Expedition to Tibet (London, Bloomsbury).

Waddell, L. A.

1906 Lhasa and its Mysteries, With a Record of the Expedition of 1903-1904 (London, Methuen \& Co.).

Wang, Xiangyun

2000 The Qing Court's Tibet Connection : Lcang skya Rol pa'i rdo rje and the Qianlong Emperor, Harvard Journal of Asiatic Studies, 60, 1, pp. 125-163. 


\section{Tibetan Works Cited}

Ngag-dbang bstan-'dzin phun-tshogs (original eighteenth-century compiler/ editor) 1979 Hor gling g.yul 'gyed (Xining, mTsho-sngon mi-rigs dpe-skrun-khang).

Sle-lung bzhad pa'i rdo-rje

(1697-1740) Dag snang ge sar gyi gtam rgyud le'u (Pure Vision of the Gesar Tale (online at Tibetan Buddhist Resource Centre tbrc.org text ref. W22130).

bSod-nams bstan-'dzin dpal-'byor

(1761-) 1987 rDo ring pandi ta'i rnam thar (smad cha) (Chengdu, Si-kron mi-rigs dpe-skrun-khang).

Sum pa mkhan po Ye shes dpal 'byor 1

(letters) Nang don tha snyad rig gnas kyi gzhung gi dogs gnas 'ga' zhig dris pa'i lan phyogs gcig tu bris pa rab dkar pa sangs, (online at Tibetan Buddhist Resource Centre tbrc.org text ref. W29227). Also found in modern reprint in $\mathrm{gNa}$ ' deng mkhas pa'i ge sar sgrung skor gyi gsung sgros gzi yi mgul rgyan (Beijing 2003, pp. 244-251) ; Also found in Damdinsuren, Ts. 1957, pp. 184-191.

Sum pa mkhan po Ye shes dpal 'byor 2 (autobiography)

2001 PaNDi ta sum pa ye shes dpal 'byor mchog gi spyod tshul brjod pa sgra'dzin bcud len (Pe cin, Mirigs dpe-skrun-khang 2001.

\section{NOTES}

1. The Ge-sar epic is certainly an important part of eastern Tibetan popular culture, but it is not as central as the contemporary prominence of Ge-sar Culture might suggest. In a survey of 53 Tibetan students from Yul-shul, mGgo-log, rMa-Iho, mTsho-byang, mTsho-lho, and mTsho-nub prefectures studying at Qinghai Education College in Xining, only two said they had heard stories of Ge-sar, while for example, all of them said they had heard stories of Akhu bstan-pa. Kun mchog dge legs et al. 1999, p. 6.

2. Arguably Lenin's greatest theoretical contribution to Twentieth century Socialism was his reconciliation in terms of the dialectic of "historical materialism", of the apparently competing and incompatible claims of "nation" and "class" as the main protagonists in what has been characterised as the great 19th century debate on the "dramatis personae of history" (Gellner 1990). In his Imperialism, the Highest Stage of Capitalism, faced with the social reality that the Soviet revolution had inherited an empire, Lenin effectively elevated oppressed nationalities to an equivalent ideological status as oppressed classes. In so doing, he laid the bedrock for the early Soviet policies of "indigenisation" or korenizatsia whereby there were strict quotas for 'native' cadres in official posts and so on (Martin 2001). Thus was born the uneasy cohabitation of two streams in Soviet nationalities policies - on the one hand, a pressure towards uniformity through economic integration, while on the other, an emphasis on "national liberation" and the nurturing of local nationality cadres, and their distinct nationality cultures. In practice these two streams proved uneasy bedfellows, as attested to by the fluctuations in fortunes of advocates of "national cultures" in the Soviet Union from the 1930s, and then the rapid dissolution of the Soviet Union in the early 1990s on the very national lines constructed by Soviet policymakers. However, this set of paradoxes was one which was imported wholesale into the Chinese context in the early 1950s, and are still being played out today.

3. For general background on Qing cultural diplomacy for the incorporation of its Inner Asian empire see for example Rawski 1998 and Millward J. et al. (eds.) 2004.

4. On the complex cultural self-image of the Manchu Qing Dynasty, and its multi-ethnic “banners" see for example Rawski 1998, pp. 59-89, 197-201, 231-263. 
5. According to Damdinsuren (1957, p. 56) this version of the Ge-sar epic is said in Mongolia to have originally been written in around 1630 in the region of Kokonor, and this woodblock edition may have been overseen by the first "Grey-Willow" Hutuktu (lcang-skya hu-tuk-tu), Ngag-dbang blo-bzang chos-ldan (d. 1714). A German translation of this text was made by Schmidt in 1839 making it the first version of the Geser/Ge-sar epic to gain a western audience. An abridged English translation was made by Ida Zeitlin in 1927 (Zeitlin 1927). It is also now available in a new abridged English version as Ge-sar! The Epic Tale of Tibet's Great Warrior King Dharma Publishing 1995.

6. On the elevation and eventual deification of Guan-di from a relatively minor character in the Three Kingdoms (San guo shi) to a Imperial protector deity and then to a Republican-era Chinese National symbol by whom officers of the Republican period had to swear oaths of allegiance, see Prasenjit Duara's excellent article on "Superscribing Symbols" : Duara 1988. On the Qing Dynasty merging of the Chinese cult of Guandi with the Tibeto-Mongol cult of Ge-sar in Central Tibet see Stein 1959, pp.111-115; Roerich 1942, pp.306-308; Hummel 1998, pp.14-16. Travellers of the period noted many Ge-sar/Guandi temples in Mongolia. As a result there was an initial confusion among foreign scholars about the identities of these two figures. Das for example may be forgiven for having confused the two figures when he wrote that Ge-sar was a king in Shanxi (China) who later became a god of war (Das 1902, p. 224). For a fuller list of references on the merging of Ge-sar and Guan-di see Hummel 1998, pp. 14-16 note 10.

7. A 'classic' Ge-sar text which exemplifies this trend - i.e. in which the role of Padmasambhava is central to the epic plot-, is the "Lingstang xylograph" version published and translated by R. A. Stein in 1956, and recently published in full English translation by Kornman et al. (trans) 2012.

8. On this see the DPhil research of Cameron Bailey, Oxford University, to which I owe this information.

9. Sle-lung's vision of Ge-sar took place in 1729 at his home monastery at 'Ol-dga' in Lho-brag, southern Tibet, when Sle-lung was thirty-two years old. In these texts, Ge-sar carries the name rDo-rje tshe-rgyal, which was a form of Ge-sar which was taken on by 'Ju Mi-pham in the late 19 th century and elaborated as a yi-dam (enlightened tutelary divinity) in Mi-pham's voluminous corpus of ritual and meditative texts centered on the figure of Ge-sar.

10. This name, or this form, of Ge-sar as an object of ritual propitiation was later picked up on by the great ris med master 'Ju Mi-pham (1846-1912), who was responsible above all others for the elaboration of a Buddhist cult of Ge-sar as a tutelary (enlightened) divinity. On this see the work of Gregory Forgues.

11. rDo ring pandi ta'i rnam thar, Volume 2 (smad cha). Chengdu. Si kron mi rigs dpe skrun khang, p. 1071.

12. In 1749, the two Manchu ambans contrived the murder of the Tibetan ruler 'Gyur-med dbangrgyal. As a result they were attacked by an angry Tibetan mob and both soon lost their lives. But the upshot of this political intrigue and drama, was a further strengthening of the Qing Military presence in the Tibetan capital. See Petech 1950a, pp. 213-18.

13. The Ge-sar/Guan-di temple in Lhasa was described by many visitors in the early 20th century. For example Waddell talked of the "Chinese temple of Ge-sar, the deified Mongol emperor of Siberia" and gave a plan of the temple (Waddell 1905, pp. 334, 40 no. 11). Roerich writing nearly forty years later, concurred that it was known as the "Chinese temple"(rgya-mi'i lha-khang) (Roerich 1942, p. 308).

14. In a short biography of the modern bard Grags-pa (1906-1986) for instance, it is stated that "in the times before Liberation, a bard, even if he was famous, had a very low status in society, similar to a butcher, a blacksmith or a shoemaker". The same source gives the oft-cited saying in "traditional" Tibet that "if you want to waste your life, then read the false tales of Ge-sar" ( $m i$ tshe gtong zad dug tong na ge sar shob sgrung la ltos). See FitzHerbert 2010, p. 221. Numerous western 
scholars have confirmed this notion that Ge-sar was and is still frowned upon, but have identified the source of this negative attitude more narrowly as being a) a specifically dGe-lugs phenomenon (Samuel 2002 p. 179) and b) even more particularly, that the approbation of Ge-sar emanates specifically from 'Bras-spungs Monastery. Nebesky Wolkowitz suggested that the source of this disapproval of the epic at 'Bras-spungs concerned the figure of Pe-har - an important dGe-lugs protector, and a deity closely associated with the gNas-chung oracle. Pe-har, he argued, appears in various suggestive guises in the Ge-sar epic as the main god of several of Ge-sar's enemies (Nebesky-Wojkowitz 1956, p. 101), so it would be inappropriate for monks to read Ge-sar and thus to be celebrating the downfall of Pe-har, since he as an important and revered protector deity. One prominent legend of Pe-har has it that he originally resided in the land of Bhata Hor as the deity gNam-the dkar-po, before being subdued by Padmasambhava and brought to bSam-yas monastery as a guardian of the treasures housed there. Well gNam-the dkar-po is the main deity of Ge-sar's greatest adversary in the epic, King Gur-dkar of Hor. Associations have also been made between Pe-har and the main deities of other Ge-sar adversaries, including King Sa-dam of 'Jang and King Shing-khri of Mon. This reason for the prohibition of Ge-sar does not however seem to be made explicit to contemporary monks of 'Bras-spungs in India. They affirm that they enjoined not to read Ge-sar, but it seems, without any specific reasons given. Two former $d G e$-bshes from 'Bras-spungs both explained the prohibition to me in terms of Ge-sar representing a worldly cultural matrix that is considered rather unBuddhist, and also that the epic was dangerous on account of being "too interesting" - and potentially powerful distraction from more edifying scholarly pursuits.

15. Byams-pa gsang-bdag (Champasangta) was a primary informant for Rene de Wojkowitz's Oracles and Demons of Tibet (1956), and for R. A. Stein's Recherches sur le Barde et l'Épopée au Tibet (1959). That the Rwa-sgreng regent kept a personal Ge-sar bard, was also likely influenced by the association maintained between the holy mountain-deity of Rwa-sgreng, Phying-dkar-ba, and the holy mountain of A-mdo closely associated with Ge-sar, A-myes rma-chen. On this see Stein 1959, Buffetrille 2009.

16. For an informative treatment of Gonlung (dgon lung) monastery see Schram 1957, pp. 26-33.

17. 6th according to the tradition of Tashilhunpo, or 3rd according to Lhasa tradition.

18. The Gosains (written 'gu bzang in Tibetan in the Panchen's biography) were a class of wandering Hindu monks-turned-traders, who came to dominate the trade between India and Tibet from around the 1730s (Petech 1950, pp. 334-335). In 1741 the Capuchin Beligatti, when describing a religious ceremony in Lhasa, observed “about 40 Azarra (ācārya), i.e. religious men from Hindustan, who are rich merchants, proceeding on horseback and wearing Chinese brocades" Magnaghi 1902, pp. 82-83, as cited by Petech 1950, p. 334. Bogle, in his journals, observed that around 150 Gosains were resident at Shigatse during his visit in 1774-1775.

19. In the letter, the Panchen states that: "the said Deh Terria [or Deb Rajah, effective ruler of Bhutan] is dependent upon the Dalai Lama, who rules in this country with unlimited sway, though, on account of his being yet in his minority, the charge and administration of the country, for the present, is committed to me." Stewart 2009 p. 22, citing Lamb Bhutan and Tibet pp. 37-38. Lamb's source in turn was Turner 1800 (1971) p. xi. The same letter is also published, in slightly different wording, by Markham 1876 (1999) pp. 1-3. The English translations were made via the medium of Persian from a Tibetan original, which might possibly still be held in Government of India archives in Calcutta.

20. According to Bogle, the Panchen had learned Hindi from his mother who was closely related to the royal house of Ladakh. For a recent treatment of Bogle's mission to Tibet, see Stewart 2009. 21. Bogle met an envoy of this Raja during his stay at Tashilhunpo. For more on relations between him and the Panchen from Tibetan sources see Petech 1950, p. 336.

22. "From Dzalandhara in the western land of the auspicious tulsi plant".

23. Sum-pa mkhan-po 2, p. 503. 
24. The Pan-chen's journey to this birthday reception has been the subject of a very readable work of popular non-fiction: Telscher 2006. This book is based primarily on Margaret Loo's translation (Loo 1970) of 'Jam-dbyangs bshad-pa's biography of the, known as the Nyi ma 'od zer.

25. According to Qianlong's inscription to commemorate founding of temple, the Xumifoushou miao "Sumeru temple" was modelled on Tashilhunpo. It was built to honour the Pan-chen's arrival. See the articles and translations by Peter Zarrow, Anne Chayet and Nyima Dorje Ragnubs in Millward et al. (eds.) 2004. Also Chayet 1985.

26. Sum-pa's autobiography - pandi ta sum pa ye shes dpal 'byor mchog gi spyod tshul brjod pa sgra 'dzin bcud len. Pe cin 2001, p. 506.

27. The question as to whether Ge-sar was originally a Tibetan or a Mongolian legend is still unsettled, with the Buryats claiming Geser as an indigenous tradition, and some scholars looking for a Monguor source. Sum-pa's assertion in this exchange of the tradition's Tibetan origins is one of the bases on which the thesis of Tibetan origins is most widely accepted by scholars.

28. Referring to Sum-pa mkhan-po's Chos-'byung dpag-bsam ljon-bzang.

29. This gter-ma text is the earliest textual attestation in Tibetan sources of legends concerning Gling Ge-sar. It was probably finally redacted around 1450 (see Stein 1962). This text is effectively the historical charter of the Rlangs clan who became rulers of Central Tibet in the mid 14th century as the Phag-mo-dru Dynasty. In it we find the 11th century ancestor of the Rlangs clan travelling to eastern Tibet where he encounters Ge-sar and his warriors, who are depicted as horse-traders. Clearly the Pan-chen lama has done some research on the question of Ge-sar's historicity.

30. Words in brackets (aside from Tibetan) give the interlinear additions in the Tibetan text.

31. This description is very similar to that of the location of the birth as revealed in the "Lingtsang woodblock" version of the epic hero's birth. This is a description of the geographical landmarks in the purported birth-place of Ge-sar at A-phyug, in the former domains of the kingdom of Gling-tshang, in modern sDe-dge county of mKhar-mdzes Tibetan Autonomous Prefecture, Sichuan Province.

32. Fol. 197, line 3. The modern Beijing reprint has the erroneous readings gzhi gnyan po and gom par tsha.

33. See discussion of this figure above.

34. The spellings given by Sum-pa of the names of the main characters in the epic are rather idiosyncratic by modern standards, but all clearly recognisable. These names of the hero's human parents are normally rendered in more modern Eastern Tibetan texts as Seng-blon and 'Gog-bza' respectively.

35. This is the famous sGrol-ma Temple at 'Dan-khog, just north of sDe-dge, on the banks of the 'Bri-chu River.

36. "placing a saddle", normally a "neck-saddle" is a Tibetan idiom for political subjugation in a wide variety of contexts, ancient and modern.

37. Personal correspondence.

38. Beijing, 2003 pp. 244-251. 


\section{ABSTRACTS}

This article presents a full English translation of an influential exchange of letters on the subject of the Ge-sar Epic between two very senior figures in late 18th century Tibet. The letters were between the 6th Pan-chen bla-ma Blo-bzang dpal-ldan ye-shes (1738-1780), and the renowned dGe-lugs-pa scholar, historian, diplomat and lama Sum-pa mkhan-po Ye-shes dpal-'byor (1704-1788). The article explores the historical context of this correspondence on the eve of the Pan-chen's visit to the Qing Imperial court on the occasion of Emperor Qianlong's 70th Birthday. Seeing this exchange in its historical context reveals the significance of the Ge-sar epic in the late 18th century as an important site of Imperial cultural diplomacy between the Tibetan, Mongolian and Manchu worlds.

Cet article présente une traduction complète en anglais d'un échange de lettres concernant l'épopée de Ge-sar entre deux figures majeures de la fin du XVIII ${ }^{\mathrm{e}}$ siècle au Tibet. Les lettres étaient entre la $\mathrm{VI}^{\mathrm{e}}$ Pan-chen bla-ma-Blo bzang dpal-ldan ye-shes (1738-1780) et le célèbre érudit, historien, diplomate et lama Sum-pa mkhan-po Ye-shes dpal-'byor (1704-1788). L'article explore le contexte historique de cette correspondance à la veille de la visite du Pan-chen à la cour impériale des Qing à l'occasion du $70^{\mathrm{e}}$ anniversaire de l'empereur Qianlong. L'étude de cet échange dans son contexte historique révèle l'importance de l'épopée de Ge-sar à la fin du XVIII ${ }^{\mathrm{e}}$ siècle comme un sujet important de la diplomatie culturelle impériale entre les mondes tibétain, mongol et mandchou.

\section{INDEX}

Mots-clés: Gesar, épopée, Tibet

Keywords: Gesar, epic, Tibet

\section{AUTHOR}

\section{SOLOMON GEORGE FITZHERBERT}

Solomon George FitzHerbert is a Departmental Lecturer in Tibetan and Himalayan Studies at Oxford University 